\title{
STRATEGI PENGEMBANGAN AGRIBISNIS KOPI ARABIKA DI KABUPATEN SIMALUNGUN
}

\section{THE DEVELOPMENT STRATEGY OF ARABICA COFFEE AGRIBUSINESS IN SIMALUNGUN REGENCY}

\author{
*Ulidesi Siadari, Jamhari, dan Masyhuri \\ Fakultas Pertanian Universitas Gadjah Mada \\ Submitted: 09-12-2018; Revised: 08-05-2019; Accepted: 17-05-2020
}

\begin{abstract}
Coffee is an important export commodity for Indonesia, which contributes a sizeable foreign exchange. Indonesian coffee production is still fluctuating. Simalungun is a regency in North Sumatera province which have significant potential for the development of Arabica coffee commodity. However, there are some obstacles in the development of arabica coffee farming including land resources utilization, aspects of cultivation, harvest and post-harvest, and institutional aspects. Therefore, it is necessary to formulate business development strategies for arabica coffe agribusiness. This study aims to determine priority strategies from various alternatives in developing Arabica coffee. Determination of the location of the study was done purposively. Respondents in this study were experts or key people who understood arabika coffee agribusiness. The method used in determining respondents is purposive sampling. Primary data is obtained through direct interviews conducted with respondents and secondary data obtained from books, journals and books of the agricultural service report. Several alternatives in this study were determined based on the results of discussions with the experts and also based on the literature and previous research. Some of these alternatives are then compared in a questionnaire for the respondents. The comparison is then processed using the analytic hierarchy process method (AHP). Data processing is done using the expert choice application so that a priority alternative appears. The study concludes that based on analytic hierarchy process, the priority strategy is developing the capacity of human resources (HR) of agribusiness actors.
\end{abstract}

Keywords: Agribusiness; Analytic Hierarchy Process; Arabica Coffee; Simalungun; The Development Strategy.

\section{ABSTRAK}

Kopi merupakan komoditas ekspor penting bagi Indonesia yang mampu menyumbangkan devisa yang cukup besar. Produksi kopi Indonesia masih berfluktuasi. Kabupaten Simalungun merupakan salah satu kabupaten di Sumatera Utara yang mempunyai potensi cukup besar untuk pengembangan komoditas kopi arabika. Namun demikian, ada beberapa kendala dalam pengembangan agribisnis kopi arabika di Kabupaten Simalungun di antaranya adalah pemanfaatan sumber daya lahan, aspek budidaya, aspek panen dan pasca panen, serta aspek kelembagaan. Oleh karena itu, perlu

*Corresponding author: Ulidesisiadari93@gmail.com.

Copyright@ 2020 THE AUTHOR (S). This article is distributed under a Creative Commons Attribution-ShareAlike 4.0 International license. Jurnal Kawistara is published by the Graduate School of Universitas Gadjah Mada. 
dirumuskan strategi pengembangan agribisnis kopi arabika yang dapat diterapkan oleh para pelaku agribisnis kopi arabika. Penelitian ini bertujuan untuk menentukan strategi prioritas dari berbagai alternatif pengembangan kopi arabika. Penentuan lokasi penelitian dilakukan secara sengaja atau purposive. Responden dalam penelitian ini merupakan para ahli atau tokoh kunci yang mengerti tentang agribisnis kopi abika. Metode yang digunakan dalam penentuan responden adalah purposive sampling. Data primer diperoleh melalui wawancara langsung yang dilakukan terhadap responden dan data sekunder diperoleh dari buku, jurnal dan buku laporan dinas pertanian. Beberapa alternatif pengembangan agribisnis dalam penelitian ini ditentukan berdasarkan hasil diskusi dengan pihak para ahli dan juga berdasarkan literaturliteratur dan penelitian terdahulu. Beberapa alternatif tersebut kemudian dijadikan sebagai pembanding dalam kuesioner yang akan ditanyakan kepada responden. Data hasil perbandingan tersebut kemudian diolah dengan menggunakan metode analisis hirarki proses (AHP). Pengolahan data dilakukan menggunakan aplikasi expert choice sehingga mucul satu alternatif prioritas. Penelitian ini menyimpulkan bahwa dalam upaya membantu pelaku agribisnis mengembangkan agribisnis kopi arabika, strategi prioritasnya adalah peningkatan kapasitas sumber daya manusia (SDM) pelaku agribisnis.

Kata Kunci: Agribisnis; Analisis Hirarki Proses; Kopi Arabika; Simalungun; Strategi Pengembangan.

\section{PENGANTAR}

Kopi merupakan salah satu komoditas yang memiliki nilai ekonomis tinggi sehingga dapat meningkatkan sumber devisa terhadap suatu negara. Negara-negara produsen kopi terbesar didunia adalah Brazil, Vietnam, Columbia dan Indonesia. Kopi yang diproduksi ada dua jenis yaitu kopi arabika dan kopi robusta. Daerah produsen kopi arabika di Indonesia salah satunya adalah Kabupaten Simalungun yang terletak di Provinsi Sumatera Utara. Kopi arabika yang dihasilkan disebut dengan Kopi Simalungun. Produksi kopi arabika di Kabupaten Simalungun berfluktuasi pada tahun 2015 produksi sebesar 52.902,10 ton, produksi tahun 2016 sebesar $38.213,52$ ton mengalami penurunan dari tahun 2015, sedangkan produksi pada tahun 2017 mengalami peningkatan dengan jumlah produksi 58.155,09 (Kementerian Pertanian, 2017).

Produksi dan produktivitas kopi arabika Simalungun mengalami penurunan. Penurunan tersebut karena sektor hulu budidaya kopi arabika terabaikan. Petani tidak melakukan peremajaan dan tidak adanya pengembangan bibit unggul sehingga petani tidak menggunakan bibit unggul dalam melakukan budidaya kopi arabika. Selain itu, petani masih melakukan sistem usahatani secara tradisional. Agribisnis kopi arabika juga mengalami kendala disektor hulu yang meliputi kelembagaan petani masih lemah, posisi tawar-menawar masih rendah, akses permodalan yang terbatas, serta kemitraan antara petani dengan industri belum sepenuhnya terwujud (Direktorat Jenderal Perkebunan, 2016). Pelatihan yang dilakukan terhadap petani merupakan salah satu cara untuk meningkatkan pengetahuan petani. Pelatihan tersebut untuk mengingkatkan pengetahuan petani dalam hal manajemen usahatani, pengendalian hama dan penyakit, serta peremajaan tanaman kopi. (Saragih, 2017).

Program yang diharapkan meningkatkan produktivitas dan kualitas kopi arabika Simalungun antara lain pengembangan model farm, pelatihan tenaga penyuluh khusus kopi spesialti, peningkatan fasilitas input, standarisasi puper dan pengolahan semi basah., pengadaan sosialisasi dan even spesialti, pengembangan pusat penelitian dan pengembangan kopi spesialti, pengembangan produk untuk regional branding, serta peningkatan infrastruktur wilayah Kabupaten Simalungun (Saragih, 2017). Beberapa alternatif untuk peningkatan produksi kopi arabika di Kabupaten Humbang Hasundutan antara lain melakukan peningkatan kualitas SDM, penguatan modal usaha dan perluasan jaringan pemasaran kopi, pengembangan kopi organik, peningkatan mutu kopi arabika melalui penanganan pasca panen yang baik, pembuatan mitra usaha, pembinaan terhadap mitra usaha, pengembangan dan pemberdaayaan kelembagaan serta manajemen 
usaha, memperbaiki rantai pemasaran. (Sihaloho, 2009).

Penelitian ini terfokus pada penentuan prioritas strategi pengembangan agribisnis kopi arabika di Kabupaten Simalungun. Penentuan kriteria, subkriteria, dan alternatif pada tulisan ini berdasarkan literatur dan pra-wawancara terhadap pihak-pihak yang terlibat dalam kegiatan agribisnis kopi arabika di Kabupaten Simalungun.

Agribisnis merupakan suatu konsep yang dibagi menjadi tiga sektor yang saling ketergantungan secara ekonomis, yaitu sektor off farm 1 (input produksi), on farm (budidaya), dan off farm 2 (produksi). Sektor masukan menyediakan perbekalan kepada para pengusaha tani untuk dapat memproduksi tanaman atau ternak seperti bibit, makanan ternak, pupuk, bahan kimia, mesin pertanian, bahan bakar, dan banyak perbekalan lainnya. Sektor produksi merupakan sektor pusat dalam usahatani. Apabila ukuran, tingkat keluaran, dan efisiensi sektor produksi bertambah, sektor lain juga akan ikut bertambah. Baik buruknya sektor ini akan berdampak langsung terhadap situasi keuangan sektor masukan dan sektor keluaran agribisnis(Andayani, 2017).

PengembanganagribisniskopidiIndonesia masih sangat potensial. Pengembangan kopi tidak hanya dilakukan oleh satu pihak, tetapi beberapa pihak yang terlibat. Pengembangan dilakukan mulai dari subsistem onfarm atau usahatani yang dilakukan oleh petani hingga subsistem off-farm yang meliputi pemasaran dan pengolahan. Subsistem penunjang dalam pengembangan agribisnis kopi arabika adalah lembaga penelitian dan lembaga pemerintah yang berperan sebagai pengambil kebijakan(Hariance, Febriamansyah, \& Tanjung, 2016).

Analisis Hirarki Proses (AHP) merupakan pendekatan dasar dalam membuat keputusan. Kekuatan perasaan dan logika digabungkan dalam metode AHP kemudian mensintesis berbagai petimbangan yang beragam menjadi suatu alternatif strategi yang prioritas (Saaty, 2008). Pengukuran dalam metode Analisis Hirarki Proses adalah menggunakan skala rasio, baik dari perbandingan berpasangan maupun kontinu. Masalah multifaktor atau multikriteria yang kompleks akan diuraikan menjadi suatu hirarki oleh AHP. Selain itu, analisis hirarki proses merupakan suatu analisis yang menggunakan pendekatan sistem dalam pengambilan keputusan (Eko Darmanto, Noor Latifah, 2014). Keunggulan dari analisis hirarki proses (AHP) adalah bersifat kompleksitas dan saling ketergantungan dalam memecahhkan permasalahan dengan melakukan pertimbangan akar permasalahan secara simultan; AHP dapat mengakomodasi pendekatan kualitatif dan kuantitatif; Penentuan pilihan dan pemeringkatan pemecahan masalah dapat menggunakan AHP sehingga diperoleh alternatif yang prioritas; AHP dapat menentukan bobot pengalokasian sumber daya yang selama ini tidak dapat dilakukan, dalam penelitian ini misalnya pengalokasin modal, sumber daya alam dan sumber daya manusia; Selain mengakomodasi pendekatan kualitatif dan kuantitatif maka AHP juga dapat mengakomodasi dan mengompromi pendapat dari berbagai pihak. Pendapat atau alternative yang dipilih berbagai pihak tersebut merupakan yang terbaik berdasarkan tujuan-tujuan mereka dan tidak memaksakan konsensus, tetapi mensistensi suatu hasil yang represesntatif dari berbagai penilaian yang berbeda-beda. Penyampaian pendapat dilakukan secara bebas, tetapi rahasia berdasarkan penilaiannya sendiri tanpa pengaruh pihak lain.

Lokasi penelitian merupakan salah satu sentra produksi kopi arabika di Sumatera Utara yaitu di Desa Purba Dolok dan Desa Sinaman II Kabupaten Simalungun. Penentuan lokasi dilakukan dengan metode purposive. Penelitian ini menggunakan pendekatan kualitatif dan dilaksanakan pada bulan Mei hingga Juni tahun 2018. Metode penentuan responden adalah purposive sampling karena responden dalam penelitian ini adalah para ahli dalam penentuan kebijakan dalam pengembangan agribisnis kopi di Kabupaten Simalungun. Berikut merupakan responden dalam penyusunan strategi pengembangan agribisnis kopi arabika di Kabupaten Simalungun. 
Tabel 1

Responden Penyusunan Strategi (keyperson)

\begin{tabular}{l|l}
\hline \multicolumn{1}{c|}{ Responden } & Jumlah Responden \\
\hline Penentu Kebijakan & \\
\hline Dinas Perkebunan Kabupaten Simalungun & 1 \\
\hline Dinas Penyuluhan Kehutanan dan Perkebunan & 1 \\
\hline Dinas Perindustrian Perdagangan dan UMKM Kabupaten Simalungun & 1 \\
\hline Pelaku Usaha & \\
\hline Kelompok tani di dua desa & 6 \\
\hline Pedagang Pengepul/Tengkulak & 1 \\
\hline Pedagang Pengumpul & 1 \\
\hline Pedagang besar kopi & 3 \\
\hline Jumlah & 14 \\
\hline
\end{tabular}

Sumber: Olah Data Penulis

Penelitian ini merupakan penelitian kualitatif. Data yang digunakan dalam penelitian ini terdiri dari data primer dan data sekunder. Data primer diperoleh ketika wawancara langsung terhadap narasumber yaitu key person atau para ahli menggunakan bantuan kuesioner. Data sekunder diperoleh dari Dinas Perkebunan, jurnal, buku, dan media internet.
Analisis data yang dilakukan dalam penentuan strategi pengembangan agribisnis kopi arabika di Kabupaten Simalungun adalah analisis hirarki proses (AHP) (Saaty, 2008). Skala banding dalam analisis hirarki proses (AHP) dimulai dari nilai 1 hingga nilai 9. Skala banding tersebut digunakan untuk menyusun alternatif prioritas. Skala banding dilihat pada tabel 1 .

Tabel 2

Skala Banding Secara Berpasangan

\begin{tabular}{|c|c|c|}
\hline $\begin{array}{c}\text { Intensitas dari kepentingan } \\
\text { pada skala absolut }\end{array}$ & Definisi & Penjelasan \\
\hline 1 & Sama pentingnya & $\begin{array}{l}\text { Kedua kriteria menyumbangkan } \\
\text { sama pada tujuan }\end{array}$ \\
\hline 3 & Sedikit lebih penting & $\begin{array}{l}\text { Pengalaman keputusan } \\
\text { menunjukkan kesukaan atas satu } \\
\text { aktivitas lebih dari yang lain }\end{array}$ \\
\hline 5 & Cukup penting & $\begin{array}{l}\text { Pengalaman dan keputusan } \\
\text { menunjukkan kesukaan atas satu } \\
\text { aktivitas lebih dari yang lain }\end{array}$ \\
\hline 7 & Sangat penting & $\begin{array}{l}\text { Pengalaman dan keputusan } \\
\text { menunjukkan kesukaan atas satu } \\
\text { aktivitas lebih dari yang lain }\end{array}$ \\
\hline 9 & Kepentingan yang ekstrem & $\begin{array}{l}\text { Bukti menyukai satu aktivitas } \\
\text { atas yang lain sangat kuat }\end{array}$ \\
\hline $2,2,6,8$ & $\begin{array}{l}\text { Nilai tengah diantara dua nilai } \\
\text { keputusan yang berdekatan }\end{array}$ & Bila kompromi dibutuhkan \\
\hline Berbalikan & $\begin{array}{l}\text { Jika aktivitas i mempunyai nilai yang } \\
\text { lebih tinggi dari aktivitas j maka j } \\
\text { mempunyai nilai berbalikan ketika } \\
\text { dibandingkan dengan i }\end{array}$ & \\
\hline Rasio & $\begin{array}{l}\text { Rasio yang didapat langsung dari } \\
\text { pengukuran }\end{array}$ & \\
\hline
\end{tabular}


Representasi dari sebuah permasalahan yang kompleks dalam suatu struktur multi level dimana level pertama adalah tujuan, yang diikuti level faktor, kriteria, subkriteria, dan seterusnya ke bawah hingga level terakhir alternative merupakan suatu hirarki (Eko Darmanto, Noor Latifah, 2014).
Kriteria, subkriteria, dan alternatif ditentukan berdasarkan wawancara dengan keyperson di lokasi pada saat pra penelitian. Data yang diperoleh pada saat prapenelitian kemudian diolah sehingga diperoleh beberapa alternatif dalam kerangka pengambilan keputusan.

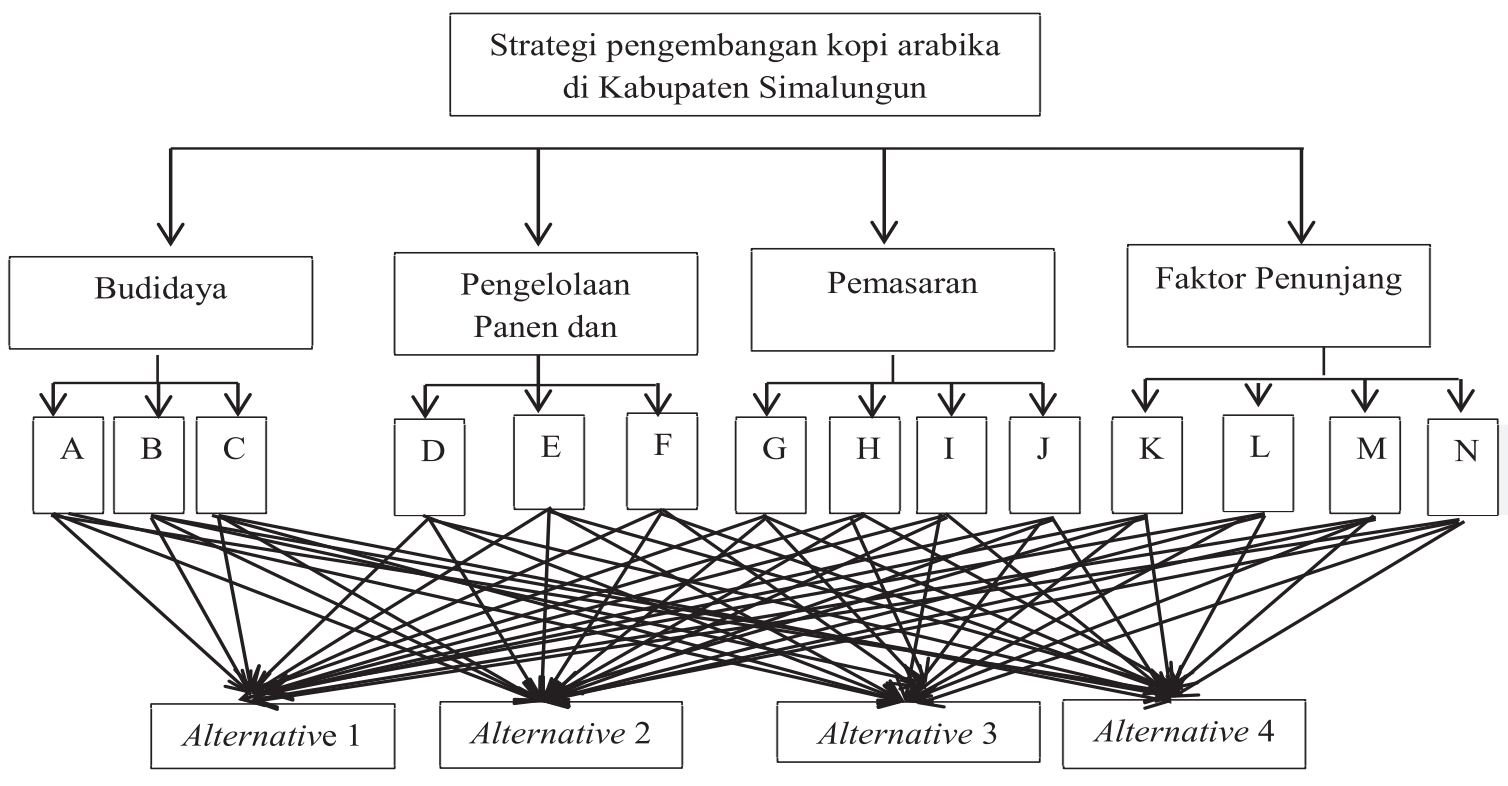

Gambar 1

Kerangka Analisis Hirarki Proses Strategi Pengembangan Kopi Arabika di Kabupaten Simalungun

Keterangan:

A : Melakukan revitalisasi dan perluasan areal tanam kopi arabika

B : Menyediakan dan memberikan bantuan sarana produksi pertanian (SAPROTAN) yang tepat waktu, jumlah, harga dan mutu.

C : Memberikan pelatihan proses budidaya kopi yang mengacu pada Good Agriculture Practice (GAP)

D : Memberikan penyuluhan terhadap petani agar melakukan penanganan yang tepat ketika panen dan juga terhadap hasil panen kopi arabika.

E : Memberikan pelatihan, inovasi serta diversifikasi produk untuk meningkatkan nilai tambah kopi.

F : Memberikan bantuan pengadaan alat pulper (mesin pengupas buah kopi basah) dan huller (mesin pengupas buah kopi kering) untuk kelompok dan dilakukan pengawasan pendampingan

G : Melakukan sosialisasi dan event kopi spesialti

$\mathrm{H}$ : Melakukan sosialisasi mengenai branding dan bimbingan sehingga mampu melakukan pemasaran dalam negeri maupun ekspor

I : Membuka peluang pasar yang menguntungkan petani

J $\quad$ : Melakukan promosi terhadap produk kopi arabika

K : Memberikan penyuluhan kepada kelembagaan sehingga terwujud penguatan efektivitas diseluruh level.

L : Memberikan bantuan modal terhadap kelompok tani.

M : Penetapan peraturan terkait dengan perlindungan harga dan tata niaga kopi 
N : Peningkatan infrastruktur wilayah Kabupaten Simalungun

Alternatif strategi dalam pengembangan kopi arabika di Kabupaten Simalungun, antara lain: (1) Peningkatan kapasitas Sumber Daya Manusia (SDM) pelaku agribisnis kopi arabika. (2) Pembangunan sistem agribisnis kopi arabika melalui perbaikan mutu dan tampilan produk (biji kopi dan olahan) yang diarahkan pada peningkatan daya saing. (3) Membina dan mendukung lembaga penelitian untun R\&D, kelompok tani dan asosiasi kopi. (4) Memperluas jaringan pasar dengan memanfaatkan kopi Indonesia yang telah dikenal dunia dan strategi penguatan branding kopi arabika Simalungun.

\section{PEMBAHASAN}

Analisis yang dilakukan menggunakan software Expert Choice 11. Alternatif strategi prioritas yang konsisten apabila memiliki nilai konsistensi $\leq$ 0,1 dengan demikian maka alternatif strategi tersebut dapat diterima (Ishizaka \& Labib, 2009). Hasil analisis menggunakan Expert Choicesebagai berikut ini:

\section{Penilaian Derajat Kepentingan Kriteria}

Perhitungan matriks perbandingan pada AHP memperesentasikan tingkat kepentingan relatif dari suatu alternatif terhadap alternatif yang lainnya. Berikut ini merupakan matriks berpasangan tingkat kepentingan antarkriteria.

Tabel 3

Matriks Berpasangan Tingkat Kepentingan antar-kriteria

\begin{tabular}{lllll}
\hline \multicolumn{1}{c}{ Kriteria } & Budidaya & Pengolahan Pascapanen & Pemasaran & Faktor Penunjang \\
\hline Budidaya & 1 & & & \\
Pengolahan Pascapanen & 1 & 1 & \\
$\begin{array}{l}\text { Pemasaran } \\
\text { Faktor Penunjang }\end{array}$ & & & 1 \\
\hline
\end{tabular}

Sumber: Data primer diolah, 2018

Penilaian derajat kepentingan terhadap kriteria strategi dalam pengembangan agribisnis kopi arabika di Kabupaten Simalungun adalah budidaya dengan bobot 0,410 . Prioritas yang kedua adalah kriteria pemasaran dengan bobot 0,240. Prioritas yang ketiga adalah pengolahan pascapanen dengan bobot 0,199, dan yang berada pada posisi terakhir adalah kriteria faktor penunjang dengan bobot 0,152 . Pada pengolahan kriteria menggunakaan bantuan aplikasi expert choice diperoleh nilai inkonsistensinya sebesar 0,03 atau $\leq 0,1$. Nilai inkonsistensi pada analisis kriteria sebesar 0,03 artinya bahwa hasil olahan data tersebut konsisten dan dapat digunakan sebagai acuan dalam perumusan strategi pengembangan agribisnis kopi arabika di Kabupaten Simalungun. Penilaian dapat dilihat pada gambar.

Priorities with respect to:

Combined

Goal: Strategi Pengembangan Kopi Arabika di Kabupaten Sim...

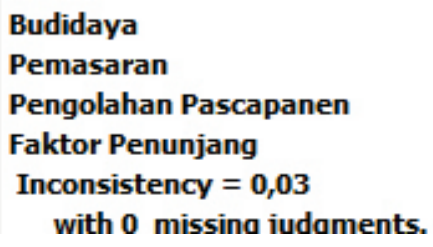

Gambar 2

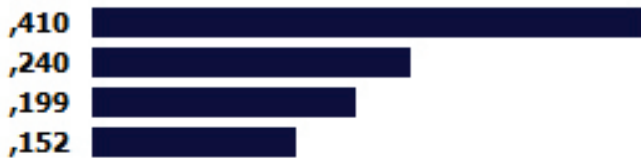

Hasil Olah Data Primer terhadap Pemilihan Prioritas Kriteria 
Budidaya yang merupakan prioritas utama di mana pengembangan budidaya kopi arabika merupakan kegiatan yang menghasilkan kopi arabika. Apabila budidaya dilakukan dengan baik atau sesuai GAP maka diperoleh kopi arabika yang memiliki kualitas yang lebih baik dari hasil sebelumnya. Pentingnya subsistem ini mendukung jalannya subsistem yang lainnya sehingga terwujud sistem agribisnis yang baik.

\section{Penilaian Derajat Kepentingan Subkriteria Penilaian derajat kepentingan subkriteria budidaya}

Penilaian derajat kepentingan subkriteria budidaya menunjukkan bahwa prioritas pada subkriteria budidaya yang sangat berpengaruh adalah memberikan pelatihan proses budidaya kopi yang mengacu pada GAP (Good Agriculture Practice) dengan bobot sebesar 0,516. Nilai inkonsistensinya sebesar 0,02 $\leq 0,1$ yang artinya hasil tersebut dikatakan konsisten. Berikut ini prioritas subkriteria pada kriteria budidaya.

Priorities with respect to:

Combined

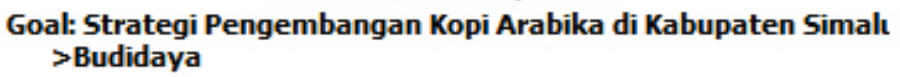

Memberikan pelatihan proses budidaya kopi yang mengacu G... , ,516

Menyediakan dan memberikan bantuan SAPROTAN

Melakukan revitalisasi dan perluasan areal tanam

,181

Inconsistency $=\mathbf{0 , 0 2}$

with 0 missing judgments.

Gambar 3

Hasil Olah Data Primer Penilaian Derajat Kepentingan Subkriteria Budidaya

\section{Penilaian Derajat Kepentingan Subkriteria Pengolahan Pascapanen}

Prioritas penilaian derajat kepentingan pada subkriteria pengolahan pascapanen adalah memberikan penyuluhan terhadap petani agar melakukan penanganan yang tepat ketika panen dan juga terhadap hasil panen kopi arabika dengan bobot sebesar
0,424. Nilai inkonsistensi pada penilaian derajat kepentingan subkriteria pengolahan pascapanen adalah sebesar 0,00157 yang artinya analisis tersebut konsisten karena lebih kecil dari 0,1. Berikut ini tingkatan prioritas subkriteria pada kriteria pengolahan pascapanen.

Priorities with respect to:

Combined

Goal: Strategi Pengembangan Kopi Arabika di Kabupaten Simalt

>Pengolahan Pascapanen

Memberikan penyuluhan agar petani melakukan penanganan... , ,424

Memberikan pelatihan, inovasi serta diversifikasi produk

, 412

Memberian bantuan pengadaan alat pulper dan huller untuk ...

,164

Inconsistency $=\mathbf{0 , 0 0 1 5 7}$

with 0 missing judgments.

Gambar 4

Hasil Olah Data Primer Penilaian Derajat Kepentingan

Subkriteria Pengolahan Pascapanen. 


\section{Penilaian Derajat Kepentingan Subkriteria Pemasaran}

Penilaian prioritas derajat kepentingan pada subkriteria pemasaran adalah melakuakn promosi terhadap kopi arabika dengan bobot sebesar 0,335. Besar nila inkonsistensinya adalah sebesar 0,01 yang artinya bahwa penilaian tersebut konsisten. Berikut ini merupakan urutan prioritas pada penilaian subkriteria pemasaran.

Priorities with respect to:

Goal: Strategi Pengembangan Kopi Arabika di Kabupaten Simalt

Combined >Pemasaran
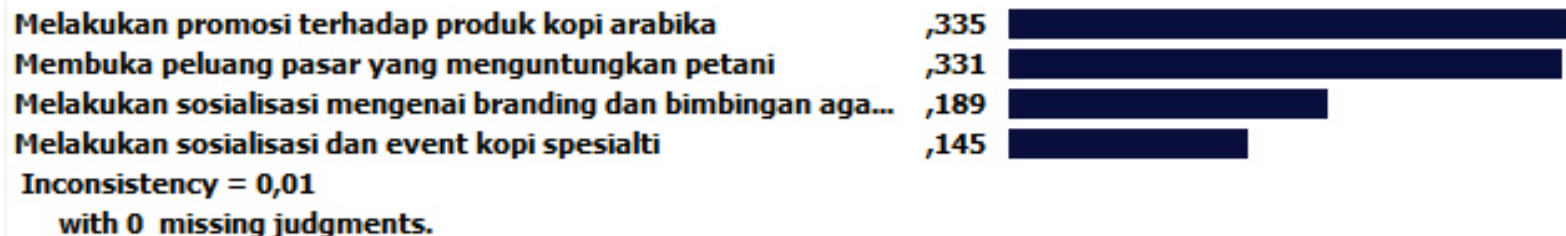

Gambar 5

Hasil Olah Data Primer Penilaian Derajat Kepentingan Kriteria Pemasaran

\section{Penilaian Derajat Kepentingan Subkriteria Faktor Penunjang}

Penilaian prioritas derajat kepentingan pada subkriteria faktor penunjang adalah memberikan penyuluhan terhadap kelembagaan dengan bobot sebesar 0,264. Bobot tersebut memiliki sedikit selisih terhadap prioritas kedua yaitu memberikan modal terhadap kelompok tani dengan bobor sebesar 0,262 . Nilai inkonsistensi sebesar 0,00967 yang artinya bahwa hasil analisis tersebut konsisten. Berikut ini urutan prioritas pada penilaian subkriteria faktor penunjang.

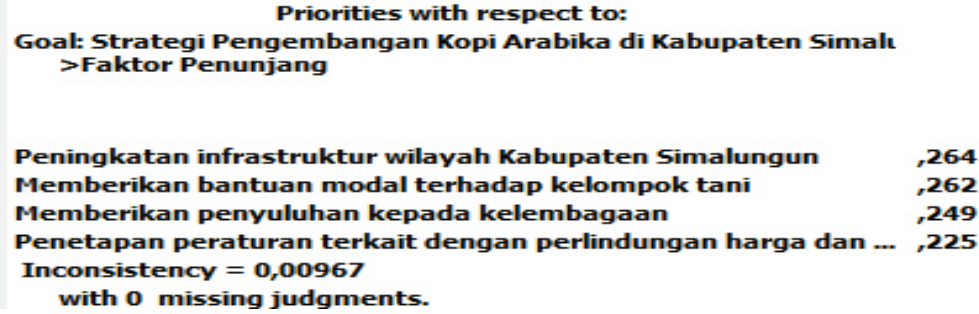

Gambar 6

Hasil Olah Data Primer Penilaian Derajat Kepentingan Subkriteria Faktor Penunjang

\section{Penentuan Prioritas Strategi Pengembangan Agribisnis Kopi Arabika}

Penentuan prioritas strategi pengembangan agribisnis kopi arabika di Kabupaten Simalungun dilakukan dengan memilih prioritas yang paling utama yang perlu dilakukan di antara alternatif-alternatif yang telah ditentukan. Alternatif-alternatif dalam strategi pengembangan agribisnis kopi arabika di Kabupaten Simalungun antara lain: Peningkatan kapasitas sumber daya manusia (SDM) pelaku agribisnis kopi arabika; Pembangunan sistem usahatani kopi arabika melalui perbaikan mutu dan tampilan produk (biji kopi dan olahan) yang diarahkan pada peningkatan daya saing; Membina dan mendukung lembaga penelitian untuk R\&D, kelompok tani dan asosiasi kopi; dan Memperluas jaringan pasar dengan memanfaatkan kopi Indonesia yang telah dikenal dunia dan strategi penguatan branding kopi arabika Kabupaten Simalungun.

Penilaian Derajat Kepentingan Alternatif Strategi terhadap 


\section{Pengembangan Subkriteria Melakukan Revitalisasi dan Perluasan Areal Tanam.}

Prioritas dalam penilaian derajat kepentingan alternatif strategi pengembangan terhadap subkriteria melakukan revitalisasi dan perluasan areal tanam kopi arabika di Kabupaten Simalungun adalah peningkatan kapasitas sumber daya manusia (SDM). Bobotnya sebesar 0,424 dan nilai inkonsistensinya adalah $0,01 \leq 0,1$ yang artinya hasil analisis tersebut konsisten. Berikut ini merupakan urutan prioritas penilaian.

\footnotetext{
Priorities with respect to:

Goal: Strategi Pengembangan Kopi Arabika di Kabupaten Simalt $>$ Budidaya

>Menyediakan dan memberikan bantuan SAPROTAN
}

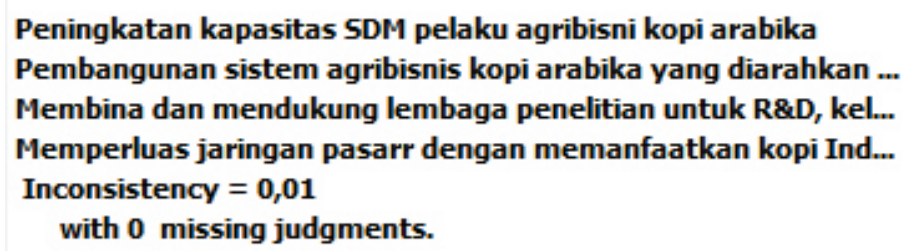

Gambar 7

Penilaian Derajat Kepentingan Alternatif terhadap Strategi Pengembangan Subkriteria Melakukan Revitalisasi dan Perluasan Areal Tanam

\section{Penilaian Derajat Kepentingan \\ Alternatif terhadap Strategi Pengembangan Subkriteria Menyediakan dan Memberikan Bantuan SAPROTAN}

Prioritas penilaian derajat kepentingan alternatif terhadap strategi pengembangan subkriteria menyediakan dan memberikan bantuan sarta produksi dan obat-obatan
(SAPROTAN) yang tepat waktu, jumlah, harga, dan mutu adalah peningkatan kapasitas SDM pelaku agribisnis kopi arabika dengan bobot sebesar 0,402. Nilai inkonsistensi yang diperoleh atas penilaian derajat kepentingan alternatif terhadap subkriteria tersebut adalah sebesar $0,01 \leq 0,1$ yang artinya bahwa penilaian tersebut konsisten. Prioritas penilaian dapat dilihat pada gambar berikut.

Priorities with respect to:

Goa: Strategi Pengembangan Kopi Arabika di Kabupaten Simalt $>$ Budidaya

>Menyediakan dan memberikan bantuan SAPROTAN

Peningkatan kapasitas SDM pelaku agribisni kopi arabika

,402

Pembangunan sistem agribisnis kopi arabika yang diarahkan ... , 246

Membina dan mendukung lembaga penelitian untuk R\&D, kel... ,197

Memperluas jaringan pasarr dengan memanfaatkan kopi Ind... ,155

Inconsistency $=\mathbf{0 , 0 1}$

with 0 missing judgments.

Combined

Gambar 8

Penilaian Derajat Kepentingan Alternatif terhadap Strategi Pengembangan Subkriteria Menyediakan dan Memberikan SAPROTAN 
Penilaian Derajat Kepentingan

Alternatif terhadap Strategi

Pengembangan Subkriteria

Memberikan Pelatihan Proses

Budidaya Kopi Mengacu GAP

Prioritas penilaian subkriteria memberikan pelatihan proses budidaya kopi arabika yang mengacu pada Good Agriculture Practice (GAP) adalah peningkatan kapasitas sumber daya manusia (SDM) dengan bobot yang signifikan dibanding dengan alternatif yang lainnya yaitu sebesar 0,584 . Nilai inkonsistensi pada penilaian derajat kepentingan alternatif ini sebesar $0,00845 \leq 0,1$ yang artinya bahwa penilaian tersebut konsisten. Urutan prioritas alternatif dapat dilihat pada gambar.

\footnotetext{
Priorities with respect to:

Goal: Strategi Pengembangan Kopi Arabika di Kabupaten Simalt $>$ Budidaya

>Memberikan pelatihan proses budidaya kopi yang men...

Combined

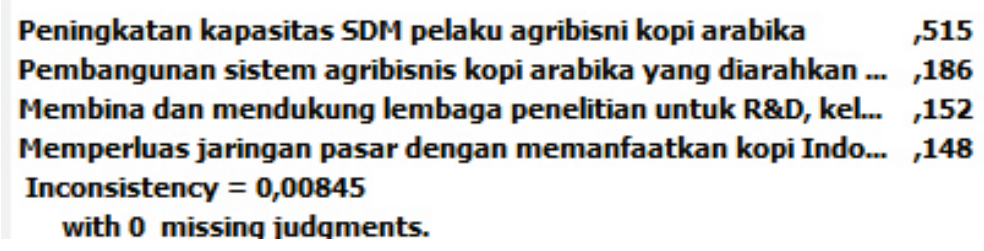

Gambar 9

Penilaian Derajat Kepentingan Alternatif terhadap Strategi Pengembangan Subkriteria Memberikan Pelatihan Proses Budidaya Kopi Arabika Mengacu pada GAP

\section{Penilaian Derajat Kepentingan Alternatif terhadap Strategi Pengembangan Subkriteria Memberikan Penyuluhan terhadap Petani}

Prioritas penilaian derajat kepentingan alternatif terhadap strategi pengembangan subkriteria memberikan penyuluhan terhadap petani adalah peningkatan kapasitas sumber daya manusia (SDM) dengan bobot sebesar
0,389. Subkriteria memberikan penyuluhan terhadap petani bertujuan agar petani melakukan penanganan yang tepat ketika panen dan penanganan yang tepat terhadap hasil panen kopi arabika di Kabupaten Simalungun. Nilai inkonsistensinya adalah $0,0045 \leq 0,1$ artinya bahwa penilaian tersebut konsisten. Urutan prioritas alternatif dapat dilihat pada gambar.

Priorities with respect to:

Combined

Goal: Strategi Pengembangan Kopi Arabika di Kabupaten Simalı $>$ Pengolahan Pascapanen

> Memberikan penyuluhan agar petani melakukan penan...

Peningkatan kapasitas SDM pelaku agribisni kopi arabika ,389

Pembangunan sistem agribisnis kopi arabika yang diarahkan ... , ,255

Membina dan mendukung lembaga penelitian untuk R\&D, kel... $\quad, 190$

Memperluas jaringan pasar dengan memanfaatkan kopi Indo... , 166

Inconsistency $=\mathbf{0 , 0 0 4 5}$

with 0 missing judgments.

Gambar 10

Penilaian Derajat Kepentingan Alternatif terhadap Strategi Pengembangan Subkriteria

Memberikan Penyuluhan terhadap Petani 


\section{Penilaian Derajat Kepentingan Alternatif Strategi terhadap Pengembangan Subkriteria Memberikan Pelatihan, Inovasi, dan Diversifikasi Produk}

Subkriteria memberikan pelatihan, inovasi, dan diversifikasi produk bertujuan untuk menambah nilai tambah kopi arabika. Nilai tembah tersebut meningkatkan pendapatan dan keuntungan petani kopi arabika.
Prioritas penilaian derajat kepentingan alternatif strategi terhadap pengembangan subkriteria memberikan pelatihan, inovasi, dan diversifikasi produk adalah peningkatan kapasitas sumber daya manusia (SDM) pelaku agribisnis dengan bobot 0,387. Nilai inkonsistensi pada penilaian ini adalah 0,00163 $\leq 0,1$ artinya penilaian tersebut konsisten. Urutan prioritas penilaian alternatif dapat dilihat pada gambar.

\footnotetext{
Priorities with respect to:

Combined

Goal: Strategi Pengembangan Kopi Arabika di Kabupaten Simalı >Pengolahan Pascapanen

>Memberikan pelatihan, inovasi serta diversifikasi produk

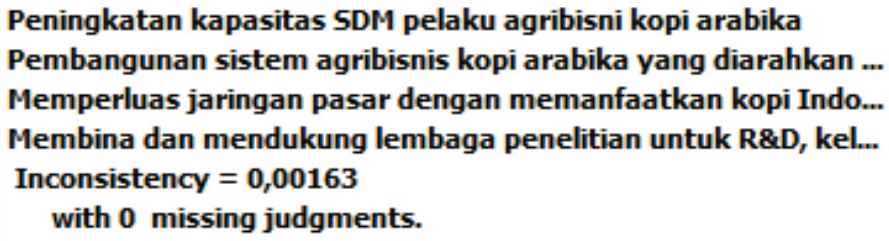

Gambar 11

Penilaian Derajat Kepentingan Alternatif terhadap Pengembangan Subkriteria Memberikan Pelatihan, Inovasi, dan Diversifikasi Produk

\section{Penilaian Serajat Kepentingan Alternatif terhadap Strategi Pengembangan Subkriteria Memberikan Bantuan Pengadaan Alat}

Subkriteria memberikan bantuan pengadaan alat berperan dalam pertambahan nilai suatu produk karena produk telah mengalami perubahan. Alat yang dimaksud dalam subkriteria ini adalah pulper dan huller. Penilaian derajat kepentingan alternatif terhadap strategi pengembangan subkriteria memberikan bantuan alat adalah peningkatan kapasitas sumber daya manusia (SDM) dengan nilai 0,363 . Prioritas terakhir adalah membina dan mendukung lembaga penelitian R\&D, kelompok tani serta asosiasi kelompok tani. Sedangkan nilai inkonsistensinya adalah $0,00095 \leq 0,1$ yang artinya bahwa penilaian tersebut konsisten. Urutan penilaian dapat dilihat pada gambar.

Priorities with respect to:

Combined

Goal: Strategi Pengembangan Kopi Arabika di Kabupaten Simalt $>$ Pengolahan Pascapanen

> Memberian bantuan pengadaan alat pulper dan huller ...

Peningkatan kapasitas SDM pelaku agribisni kopi arabika

Pembangunan sistem agribisnis kopi arabika yang diarahkan ... , 273

Memperluas jaringan pasar dengan memanfaatkan kopi Indo... , 198

Membina dan mendukung lembaga penelitian untuk R\&D, kel... , 166

Inconsistency $=\mathbf{0 , 0 0 0 9 5}$

with 0 missing judgments.

Penilaian Derajat Kepentingan Alternatif Strategi Pengembangan Subkriteria Memberikan Bantuan Pengadaan Alat 
Penilaian Derajat Kepentingan Alternatif Strategi terhadap Pengembangan Subkriteria Melakukan Sosialisasi dan Event Kopi Spesialti

Prioritas penilaian derajat kepentingan alternatif strategi terhadap pengembangan subkriteria melakukan sosialisasi dan event kopi spesialti adalah pembangunan sistem agribisnis kopi arabika dengan bobot sebesar 0,369 . Nilai inkonsistesinya adalah sebesar

Priorities with respect to:

Goal: Strategi Pengembangan Kopi Arabika di Kabupaten Simalı $>$ Pemasaran

>Melakukan sosialisasi dan event kopi spesialti
$0,00364 \leq 0,1$ yang artinya bahwa penilaian tersebut konsisten. Pembangunan sistem agribisnis kopi arabika dimaksud untuk perbaikan mutu dan tampilan produk (biji kopi dan kopi olahan) yang diarahkan pada peningkatan daya saing sehingga pemasaran kopi arabika Simalungung meningkat. Urutan penilaian dapat dilihat pada gambar berikut.

Pembangunan sistem agribisnis kopi arabika yang diarahkan ... Peningkatan kapasitas SDM pelaku agribisni kopi arabika

,369 ,281

Memperluas jaringan pasar dengan memanfaatkan kopi Indo... ,235

Membina dan mendukung lembaga penelitian untuk R\&D, kel... ,115

Inconsistency $=\mathbf{0 , 0 0 3 6 4}$

with 0 missina iudaments.

Gambar 13

Penilaian Derajat Kepentingan Alternatif terhadap Strategi Subkriteria Melakukan Sosialisasi dan Event Kopi Spesialti

\section{Penilaian Derajat Kepentingan Alternatif terhadap Strategi Pengembangan Subkriteria Melakukan Sosialisasi Mengenai Branding dan Bimbingan}

Prioritas penilaian derajat kepentingan alternatif terhadap strategi pengembangan subkriteria melakukan sosialisasi mengenai branding dan bimbingan adalah peningkatan kapasitas sumber daya manusia (SDM) pelaku agribisnis dengan bobot sebesar 0,334. Sosialisasi mengenai branding dan bimbingan bertujuan agar produk mampu dipasarkan di dalam maupun di luar negeri. Nilai inkonsistensi pada penilaian sebesar 0,00162 $\leq$ 0,1 artinya penilaian tersebut konsisten. Urutan prioritas dapat dilihat pada gambar berikut.

Priorities with respect to:

Combined

Goal: Strategi Pengembangan Kopi Arabika di Kabupaten Simalt $>$ Pemasaran

> Melakukan sosialisasi mengenai branding dan bimbing...

Peningkatan kapasitas SDM pelaku agribisni kopi arabika ,334

Memperluas jaringan pasar dengan memanfaatkan kopi Indo... ,266

Pembangunan sistem agribisnis kopi arabika yang diarahkan ... , 245

Membina dan mendukung lembaga penelitian untuk R\&D, kel... ,155

Inconsistency $=\mathbf{0 , 0 0 1 6 2}$

with 0 missing judgments.

\section{Gambar 14}

Penilaian Derajat Kepentingan Alternatif terhadap Pengembangan Subkriteria Melakukan Sosialisasi Mengenai Branding dan Bimbingan 


\section{Penilaian Derajat Kepentingan Alternatif terhadap Strategi Pengembangan Subkriteria Membuka Peluang Pasar yang Menguntungkan Petani.}

Memperluas jaringan pasar merupakan prioritas utama pada penilaian derajat kepentingan alternatif terhadap strategi pengembangan subkriteria membuka peluang pasar yang menguntungkan petani dengan bobot sebesar 0,377. Nilai inkonsistensinya adalah sebesar 0,00148 $\leq 0,1$ artinya penilaian tersebutkonsisten. Memperluas jaringan pasar yang dimaksud adalah dengan memanfaatkan kopi Indonesia yang telah dikenal dunia dan melalui strategi penguatan branding kopi arabika Simalungun. Apabila jaringan pasar diperluas maka petani dapat memasarkan kopi yang dihasilkan sesuai dengan harga yang diharapkan oleh petani sehingga petani memproleh keuntungan seperti yang diharapkan. Strategi pengembangan agribisnis kopi di Indonesia yaitu memperluas jaringan pasar dilakukan dengan memanfaatkan kopi di Indonesia yang telah dikenal dunia, pengembangan bioteknologi dan peningkatan pasar sasaran(Santoso, et.al, 2013). Urutan prioritas dapat dilihat pada gambar berikut.

Priorities with respect to:

Combined

Goal: Strategi Pengembangan Kopi Arabika di Kabupaten Simalt

$>$ Pemasaran

>Membuka peluang pasar yang menguntungkan petani

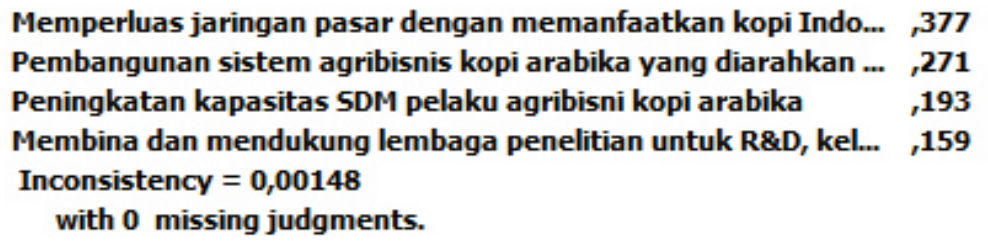

Gambar 15

Penilaian Derajat Kepentingan Alternatif terhadap Pengembangan Subkriteria Membuka Peluang Pasar

Tercapainya kapasitas produksi karena adanya kerja sama antara petani dengan pengusaha pemasok bahan-bahan pertanian. Pengembangan jaringan pasar yang sesuai dikembangkan berdasarkan informasi pasar yang lengkap sehingga jaringan pemasaran dapat menjangkau seluruh potensi pasar. (Zakaria, Aditiawati, \& Rosmiati, 2017).

\section{Penilaian Derajat Kepentingan Alternatif terhadap Strategi Pengembangan Subkriteria Melakukan Promosi terhadap Produk Kopi Arabika.}

Memperkenalkan produk-produk kopi ke daerah target pemasaran baru merupakan salah satu strategi dalam pengembangan pasar. (Kartika, Rifin, \& Saptono, 2018). Prioritas penilaian derajat kepentingan alternatif terhadap strategi pengembangan subkriteria melakukan promosi terhadap produk kopi arabika adalah memperluas jaringan pasar dengan nilai 0,320. Memperluas jaringan pasar akan meningkatkan promosi terhadap produk kopi arabika Simalungun. Nilai inkonsitensi pada penilaian ini adaah sebesar 0,01 $\leq 0,1$ artinya penilaian tersebut konsisten. Urutan penilaian dapat dilihat pada gambar berikut. 
Priorities with respect to:

Combined

Goal: Strategi Pengembangan Kopi Arabika di Kabupaten Simalt

$>$ Pemasaran

>Melakukan promosi terhadap produk kopi arabika

Pembangunan sistem agribisnis kopi arabika yang diarahkan ...

Memperluas jaringan pasar dengan memanfaatkan kopi Indo...

Peningkatan kapasitas SDM pelaku agribisni kopi arabika

, 320

Membina dan mendukung lembaga penelitian untuk R\&D, kel... ,130

Inconsistency $=\mathbf{0 , 0 1}$

with 0 missing judgments.

Gambar 16

Penilaian Derajat Kepentingan Alternatif Terhadap Strategi Pengembangan Subkriteria Melakukan Promosi Produk Kopi Arabika

\section{Penilaian Derajat Kepentingan \\ Alternatif terhadap Strategi \\ Pengembangan Subkriteria \\ Memberikan Penyuluhan kepada \\ Kelembagaan}

Prioritas penilaian derajat kepentingan aternatif terhadap strategi pengembangan subkriteria memberikan penyuluhan kepada kelembagaan adalah peningkatan kapasitas sumber daya manusia (SDM) dengan bobot sebesar 0,477 . Nilai inkonsistesi pada penilaian ini adalah $0,02 \leq 0,1$ yang artinya bahwa penilaian tersebut konsisten. Memberikan penyuluhan terhadap kelembagaan bertujuan agar terwujud penguatan efektivitas di seluruh level. Urutan prioritas alternatif dapat dilihat pada gambar.

Priorities with respect to:

Combined

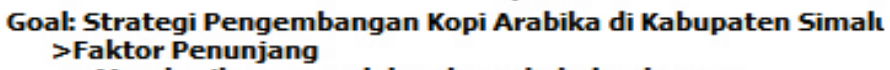

Peningkatan kapasitas SDM pelaku agribisni kopi arabika

Pembangunan sistem agribisnis kopi arabika yang diarahkan

Memperluas jaringan pasar dengan memanfaatkan kopi Indo... , ,159

Membina dan mendukung lembaga penelitian untuk R\&D, kel... , 150

Inconsistency $=0,02$

with 0 missing judgments.

Gambar 17

Penilaian Derajat Kepentingan Alternatif terhadap Subkriteria Kepentingan

Memberikan Penyuluhan kepada Kelembagaan sehingga Terwujud

Penguatan Efektivitas di Seluruh Level

\section{Penilaian Derajat Kepentingan Aternatif terhadap Strategi Pengembagan Subkriteria Memberikan Modal terhadap Kelompok Tani}

Prioritas penilaian derajat kepentingan alternatif terhadap strategi pengembangan subkriteria memberikan modal terhadap kelompo tani adalah peningkatan kapasitas sumber daya manusia (SDM) pelaku agribisnis dengan bobot sebesar 0,438. Apabila pelaku agribisnis memiliki kapasitas SDM yang baik maka modal yang dimiiki oleh pelaku agribisnis dapat dikelola dengan baik sehingga petani memperoleh keuntungan yang optimal dan tidak rugi. Nilai inkonsistensi pada penilaian ini adalah $0,03 \leq 0,1$ artinya penilaian tersebut konsisten. Urutan prioritas penilaian alternatif dapat dilihat pada gambar. 
Priorities with respect to:

Goal: Strategi Pengembangan Kopi Arabika di Kabupaten Simalt $>$ Faktor Penunjang

$>$ Memberikan bantuan modal terhadap kelompok tani

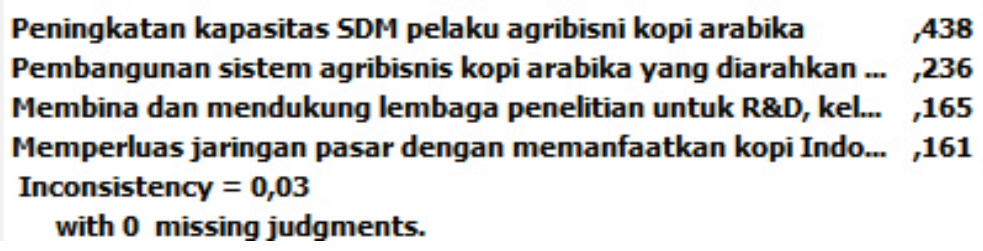

Memberikan Modal terhadap Kelompok Tani

\section{Penilaian Derajat Kepentingan Alternatif terhadap Strategi Pengembangan Subkriteria Penetapan Peraturan}

Menetapkan harga dilakukan setelah melihat ancaman yang berasal dari luar, seperti ketersediaan bahan baku dan harga bahan baku (Alhidayat, 2018). Pembangunan sistem agribisnis kopi arabika yang diarahkan pada peningkatan daya saing merupakan prioritas dalam penilaian derajat kepentingan alternatif terhadap strategi pengembangan subkriteria penetapan peraturan terkait

>Penetapan peraturan terkait dengan perlindungan har...

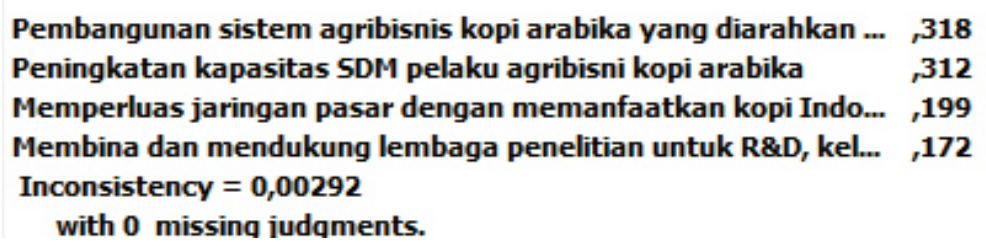

Gambar 19

Penilaian Derajat Kepentingan Alternatif terhadap Pengembangan Subkriteria Penetapan Peraturan

Penilaan Derajat Kepentingan

Alternatif Strategi terhadap Pengembangan Subkriteria Peningkatan Infrastruktur Wilayah Kabupaten Simalungun
Infrastruktur merupakan salah satu faktor penunjang dalam agribisnis kopi arabika di Kabupaten Simalungun. Prioritas alternatif pada subkriteria ini adalah memperluas jaringan pasar dengan memanfaatkan kopi Indonesia yang telah dikenal dunia dan strategi penguatan 
branding kopi arabika Kabupaten Simalungun dengan bobot sebesar 0,277.Jaringan pasar yang luas maka Kabupaten Simalungun yang merupakan sentra pertanian mampu mengakses pasar dengan mudah sehingga pihak yang terlibat dalam agribisnis kopi arabika di Kabupaten Simalungun diuntungkan. Nilai inkonsistensinya adalah sebesar $0,00 \leq 0,1$ artinya penilaian tersebut konsisten. Urutan prioritas peilaian dapat dilihat pada gambar.

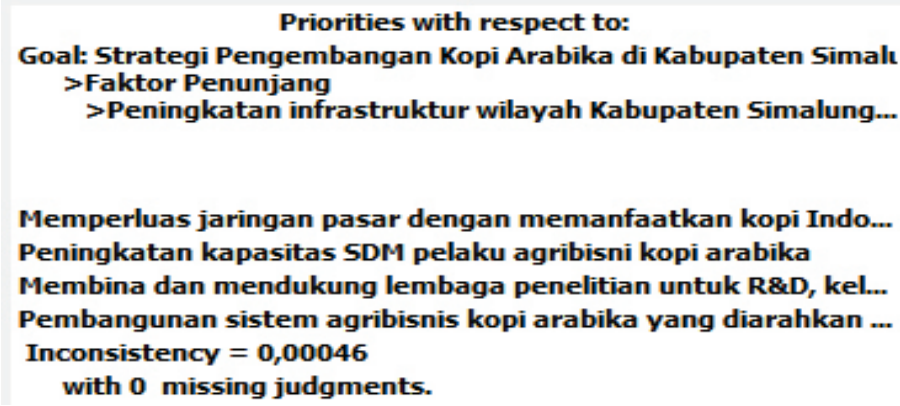

Gambar 20

Penilaian Derajat Kepentingan Alternatif terhadap Pengembangan Subkriteria Peningkatan Infrastruktur Wilayah Kabupaten Simalungun

\section{Penentuan Strategi Pengembangan Agribisnis Kopi Arabika}

Berdasarkan kriteria-kriteria dan subkriteria dalam pemilihan strategi pengembangan agribisnis kopi arabika di Kabupaten Simalungun maka yang menjadi alternatif prioritas utama adalah peningkatan kapasitas sumber daya manusia (SDM) pelaku agribisnis kopi arabika di Kabupaten Simalungun dengan bobot sebesar 0,370 . Nilai inkonsistensi pada penilaian tersebut adalah sebesar 0,02 $\leq 0,1$ artinya penilaian tersebut konsisten. Berdasarkan kenyataan yang ada didaerah penelitian, para pelaku agribisnis terutama para petani kopi arabika memiliki kapasitas SDM yang masih perlu untuk ditingkatkan. Petani ketika melakukan budidaya tanaman kopi arabika masih dengan cara lama seperti yang dilakukan oleh petani sebelumnya dengan kata lain masih tradisional dan tidak sesuai dengan good agriculture practice (GAP). Kendala yang dihadapi oleh pemerintah adalah kesulitan ketika mengajak petani untuk berdiskusi tentang pertanian yang ada di Kabupaten Simalungun terutama terkait dengan kopi arabika. Dengan demikian, prioritas peningkatan kapasitas sumber daya manusia (SDM) pelaku agribisnis kopi arabika di Kabupaten Simalungun adalah tepat. Strategi pengembangan sumber daya (SDM) pelaku agribisnis bertujuan melahirkan pelaku agribisnis yang memiliki daya saing tinggi, dengan daya saing yang tinggi tersebut maka para pelaku agribisnis mampu menhadapi persaingan global (Fadhil, Maarif, Bantacut, \& Hermawan, 2017). Urutan prioritas strategi pengembangan agribisnis kopi arabika dapat dilihat pada gambar berikut.

Combined instance -- Synthesis with respect to:

Goal: Strategi Pengembangan Kopi Arabika di Kabupaten Simalungun

Overall Inconsistency $=, 02$

Peningkatan kapasitas SDM pelaku agribisni kopi arabika

Pembangunan sistem agribisnis kopi arabika yang diarahkan pada peningkatan daya saing

Membina dan mendukung lembaga penelitian untuk R\&D, kelompok tani dan asosiasi kopi

Memperluas jaringan pasar dengan memanfaatkan kopi Indonesia yang telah dikenal dunia dan strat...

370

250

166

.214

Gambar 21

Hasil Olah Data Primer Penentuan Prioritas Strategi Pengembangan

Agribisnis Kopi Arabika di Kabupaten Simalungun 
Prioritas urutan kedua adalah pembangunan sistem agribisnis kopi arabika yang diarahkan pada peningkatan daya saing dengan bobot 0,250. Prioritas urutan ketiga adalah memperluas jaringan pasar dengan memanfaatkan kopi Indonesia yang telah dikenal dunia dan strategi penguatan branding kopi arabika Kabupaten Simalungun. Urutan terakhir adalah alternatif membina dan mendukung lembaga penelitian untuk $R \& D$, kelompok tani, dan asosiasi kopi dengan nilai 0,166 .

Berdasarkan kenyataan di daerah penelitian, para pelaku agribisnis terutama para petani kopi memiliki kapasitas sumber daya manusia (SDM) yang masih perlu ditingkatkan. Petani ketika melakukan budidaya tanaman kopiarabika masih dengan cara lama seperti yang dilakukan petani sebelumnya yang masih tradisional dan tidak sesuai dengan good agriculture practice (GAP). Dengan demikian maka strategi prioritas dalam pengembangan agribisnis kopi arabika di Kabupaten Simalungun adalah Peningkatan kapasitas sumber daya manusia (SDM) pelaku agribisnis kopi arabika.

\section{SIMPULAN}

Kabupaten Simalungun merupakan wilayah sentra produksi kopi arabika yang memiliki ketinggian wilayah 900-1.400 meter diatas permukaan laut. Keadaan iklim Simalungun tersebut sangat cocok untuk budidaya kopi arabika. Agribisnis kopi arabika di Kabupaten Simalungun memiliki produksi dan produktivitas yang belum maksimal sehingga pelaku usaha agribisnis belum memperoleh keuntungan yang optimal. Alternatif strategi utama dalam pengembangan agribisnis kopi arabika di Kabupaten Simalungun adalah peningkatan kapasitas sumber daya manusia (SDM) pelaku agribisnis kopi arabika dengan bobot sebesar 0,370. Urutan yang kedua adalah pembangunan sistem agribisnis kopi arabika melalui perbaikan mutu dan tampilan produk (biji kopi olahan) yang diarahkan pada peningkatan daya saing dengan nilai 0,250. Pada urutan yang ketika adalah memperluas jaringan pasar dengan memanfaatkan kopi
Indonesia yang telah dikenal dunia dan strategi penguatan branding kopi arabika Kabupaten Simalungun dengan nilai 0,214. Sedangkan pada urutan terakhir adalah alternatif membina dan mendukung lembaga penelitian untuk R\&D, kelompok tani, dan asosiasi kopi dengan nilai 0,166 . Nilai inkonsistensi pada penilaian ini adalah sebesar 0,02 $\leq 0,1$ artinya penilaian tersebut konsisten.

Peningkatan sumber daya manusia (SDM) pelaku agribisnis kopi arabika di Kabupaten Simalungun harus ditekankan sehingga para pelaku agribisnis memiliki kemampuan yang baik dalam mengelola usaha tersebut. Memberikan pelatihan terhadap pelaku usaha kopi arabika sehingga petani mengetahui dan memperoleh bibit unggul yang baik, melakukan perawatan dan pemeliharaan tanaman yang baik, dan melakukan proses pemanenan dan pascapanen yang sesuai. Pemahaman yang baik tersebut akan memberikan kesadaran bagi petani dan pelaku agribisnis lainnya bagaimana pentingnya prosedur yang tepat dalam usaha agribisnis kopi arabika. Apabila semua pelaku agribisnis menyadari betapa pentingnya prosedur yang tepat maka agribisnis kopi arabika di Kabupaten Simalungun akan lebih baik.

\section{DAFTAR PUSTAKA}

Alhidayat, R. (2018). Strategi Pengembangan Industri Kecil Pengolahan opi Bubuk di Kabupaten Kepahiang Provinsi Bengkulu. Jurnal Aghinya Stesnu Bengkulu, 8(1).

Andayani, S. A. (2017). Manajemen agribisnis. (Y. Farlina, Ed.). Bandung: CV. Media Cendikia Muslim.

Direktorat Jenderal Perkebunan. (2016). Statistika Perkebunan Indonesia. Jakarta.

Eko Darmanto, Noor Latifah, N. S. (2014). Penerapan Metode AHP (Analythic Hierarchy Process ) Untuk Menentukan Kualitas Gula Tumbu Eko. Jurnal SIMETRIS, 5(1):75-82.

Fadhil, R., Maarif, M. S., Bantacut, T., \& Hermawan, A. (2017). Model Strategi 
Pengembangan Sumber Daya Manusia Agroindustri Kopi Gayo dalam Menghadapi Masyarakat Ekonomi ASEAN. Jurnal Manajemen Teknologi, 16(2): 141-156.

Hariance, R., Febriamansyah, R., \& Tanjung, F. (2016). Development Strategy of Robusta Coffee Agribusiness in District of Solok. AGRISEP, 15(1): 111-126.

Heru Santoso, Fitria Dina Riana, L. F. K. (2013). Analisis Permintaan dan Strategi Pengembangan Agribisnis Kopi di Indonesia, XIII(1).

Ishizaka, A., \& Labib, A. (2009). Analytic Hierarchy Process and Expert Choice: Benefits and limitations. OR Insight, 22(4):201-220. https://doi. org/10.1057/ori.2009.10

Kartika, Y. D., Rifin, A., \& Saptono, I. T. (2018). Strategi Pengembangan Usaha Pengolahan Kopi arabika (Studi kasus PT. Golden Malabar). Jurnal Aplikasi Manajemen Dan Bisnis, 4(2): 212-219.
Kementerian Pertanian. (2016). Laporan Tahunan Kementerian Pertanian. Jakarta.

Saaty, T. L. (2008). Decision making with the analytic hierarchy process. International Journal of Services Sciences, 1(1):87.

Saragih, J. R. S. (2017). Socioecological aspect of arabica coffee farming in highland of simalungun district north sumatera. Jurnal Sosiohumaniora, 19(3): 253-259.

Sihaloho, T. M. (2009). StrategiPengembangan Agribisnis Kopi di Kabupaten Humbang Hasundutan Sumatera Utara. Institut Pertanian Bogor.

Zakaria, A., Aditiawati, P., \& Rosmiati, M. (2017). Strategi Pengembangan Usahatani Kopi Arabika (Kasus pada Petani Kopi Di Desa Suntenjaya Kecamatan Lembang Kabupaten Bandung Barat, Provinsi Jawa Barat). Jurnal Sosioteknologi, 16(3):325-339. 